\title{
Organization of network educational projects in the training of teachers of geography
}

\author{
Anna Ertel $^{1}$, Vladimir Latun ${ }^{1 *}$, Ivan Bogachev ${ }^{1}$, and Ludmila Nedoseka ${ }^{1}$ \\ ${ }^{1}$ Southern Federal University, 344000, Zorge str., 40, Rostov-on-Don, Russia
}

\begin{abstract}
Qualitative changes based on the development of information technologies affect all aspects of people's lives today, including school educational practical training. The article discusses the possibilities of using network educational projects in teachers training based on shared access services and modern digital educational platforms. The use of network educational projects in teaching practice makes it possible to achieve new educational results in the context of the globalization of education competition in various countries. The spread of "network" culture affects the organization of professional training for teachers, diversification of educational programs and educational institutions, the effectiveness of the organization of lifelong learning, education coverage of all participants in the educational process. The use of network educational projects in the practice of a geography teacher changes his role in organizing the educational process of mastering educational programs in geography.
\end{abstract}

\section{Introduction}

Modern pedagogical science has always been focused on the connection between learning and life. However, this condition was interpreted differently in different periods of the country's development. Today, in the education system, a necessary condition for its development is the information and educational environment. Networks constitute a new social morphology of human communities, and the spread of "network" logic is increasingly affecting people's daily life, which determines the great contribution of science, innovation and new technologies to education [1-2]. The history of the development of education in Russia shows various ways of transformation [3]. In 1954, D. Barens first introduced the concept of a social network as an analytical concept into scientific discourse [4]. In the studies of Garton Haythronthwaite and Wellman, the nature of networked communities is considered, which is considered as the concept of "a social network", defined by a set of social relationships, such as friendship, joint work activities or information exchange [5]. Today information and educational environment are a necessary condition for the development of the education system. Networks constitute a new social morphology of human communities, and the spread of "network" logic is increasingly affecting people's daily lives. Digital devices and network services are increasingly involving people in a new collaborative environment [6]. All these changes in the

\footnotetext{
${ }^{*}$ Corresponding author: vlatun@yandex.ru
} 
organization of educational work require a transition to a new model of school work. For such a transition in modern conditions, there are all the conditions: collections of digital resources and media applications on the websites of publishing houses, the active introduction of electronic forms of textbooks into the practice of teachers, the experience of creating a model of the Russian electronic school in certain regions of the country, etc. One of the most effective technologies for including digital resources in educational practical training becomes the organization of educational projects for teachers and school teams [7].

\section{Materials and research methods}

The study of the pedagogical features of the training of geography teachers was based on the work of domestic and foreign scientists, geographers and educators who studied the relationship between innovation processes and effects (N.F. Rodionova, L.V. Smorgunova), the methodology of network organization in relation to innovative processes in education (A.I.Adamsky. T.A.Zubareva, O.D.Fedotova), issues of using network interaction for the innovative development of educational institutions (N.E. Orlikhina, N.S. Bugrova, N.L. Gololobova, E.V. Chernobay), organization issues project activities in the context of school informatization (E.S. Polat).

The inclusion of network project activities in the organization of training geography teachers requires changes in teaching technologies, the development of digital resources for conducting network educational projects, a reasonable choice of free access services and digital platforms for use in the educational process, the development of educational and methodological materials to accompany participants [8].

A package of diagnostic materials (questionnaires, tests, methods of collecting and processing information) has been prepared to carry out diagnostic procedures to determine the effectiveness of pedagogical interventions through the organization of network project activities of teachers. Within the framework of the study, they are differentiated according to two criteria: the criterion of personal professional development and the criterion of network activity in the information and educational environment.

The indicators of the criterion of personal professional development were determined: participation of geography teachers in advanced training programs, other forms of education and network activity; formation of professional ICT competence in the learning process; analysis of publication activity, placement of materials illustrating the experience of implementing educational programs on the pages of regional network communities and websites of educational organizations; the readiness of teachers for self-education and selfdevelopment (determining the dynamics of participation in network educational projects for teachers and school teams, experience in the development and implementation of author's teacher projects for schoolchildren); the number of educational, methodological and electronic educational resources created by teachers.

The criterion of network activity in the educational information environment was considered on the basis of the following indicators: the use of innovative pedagogical and managerial practices by teachers of regional banks; participation of teachers in the work of professional networked educational communities (quantitative data and their interpretation in comparison with the data of questionnaires of teachers of geography of Rostov region), creation of platforms for network interaction between teachers and students, created on the basis of the websites of educational organizations.

Since 2013, network educational projects have been used in the practice of teaching geography teachers in Rostov region in the system of additional professional education. Let us consider in more detail their place in the system of professional support of teachers, both during the training period and after the completion of educational activities as part of refresher courses. The basis for the organization of network project activities was the 
network community of geography teachers, which was created to accompany teachers enrolled in additional professional education programs. The creation of a network community has become important for determining the target audience, those who will become a participant in network learning and, in further, interaction. To study the level of ICT competence, an entrance test was carried out, on the basis of which the levels of teachers' readiness to work in the network were identified. Diagnostic materials were created based on the requirements of the professional standard "Educator" [9]. The teacher and the trainees used various forms of communication that can be implemented in the network community: the publication of announcements, news (the leading functions are motivational, incentive, influence); creating a blog (leading functions - understanding, establishing relationships); organization of discussions in forums that are organized nonlinearly (leading functions are motivational, understanding, establishing relationships, influencing, informational); organizing discussions of ideas, emerging problems, evaluating the results of one's own work and the work of participants (leading functions - motivational, establishing relationships, contact, understanding); exchange of messages between all participants of communication within the course (leading functions - motivation, establishing relationships, contact, incentive, understanding, coordination, information) [10].

To equalize the level of ICT competence of teachers, workbooks, educational and teaching aids, guidelines for teachers were developed. Compulsory assignments performed in the process of teacher training were included in the methodological bank, which was designed in the form of a student promotion table (using Web-2.0 network services). In the student's methodological bank, all the obligatory tasks were collected, which all the participants in the training could get acquainted with.

At the second stage of training, teachers were invited to participate in various forms of network communication on the platform of the network community "Teachers of Geography of Rostov Region": to organize a forum for discussing professional difficulties or instructional and methodological documents in the field of the subject being taught, to conduct a master class or project, to post an outline plan lesson, take part in a webinar or web conference. The main criterion for the effectiveness of such work is to attract more participants. At this stage, teachers could prove themselves in different roles: an attentive and benevolent expert; organizer of a common cause; a successful leader responsible for a part of the common cause; a person who overcomes personal communication barriers; a person cooperating; a person who is creative in learning. At this stage, teachers can act as the organizer of the educational project; designer of interaction and cooperation forms; organizer of communicative situations at the thematic forum; facilitator of the reflective attitude of listeners to the content of didactic materials on the subject; organizer of situations of overcoming individual barriers to communication; a person who encourages network communication [11]. During this period, teachers received practical skills in social networks behavior. Professional support from the teacher was implemented through the organization of network educational projects for teachers.

The educational activities of the third stage were implemented after the completion of the training of teachers of geography of Rostov region and were aimed at joint network activities of teachers and schoolchildren. At this stage, the role of the teacher is professional and informational support of network educational projects for school teams, developed by the training participants. As the practice of accompanying them has shown, this form of organizing the activities of teachers and students together is in demand and is attracting an increasing number of participants (Table 1). 
Table 1. Dynamics of the participation of geography teachers in network educational projects

\begin{tabular}{|c|c|c|c|}
\hline Year & Project & $\begin{array}{c}\text { Number of } \\
\text { participant } \\
\text { s }\end{array}$ & Project link \\
\hline 2013 & Regional project "As it is on the Don" & 28 & http://goo.gl/AobAsw \\
\hline 2014 & All-Russian project "Pearls of the Earth" & 35 & $\begin{array}{c}\text { https://goo.gl/NDd2H } \\
\text { w }\end{array}$ \\
\hline 2015 & International project "I want to know all!" & 38 & https://goo.gl/Pw7eyu \\
\hline 2016 & $\begin{array}{l}\text { International project "Methodological } \\
\text { navigator" }\end{array}$ & 118 & $\begin{array}{c}\text { https://goo.gl/ueBAZ } \\
\text { U }\end{array}$ \\
\hline 2017 & Regional project "80 years of Rostov region". & 189 & https://goo.gl/iHSqEf \\
\hline 2018 & $\begin{array}{l}\text { All-Russian project "Methodical Navigator. } \\
\text { Russian language" }\end{array}$ & 155 & https://goo.su/22pS \\
\hline 2018 & $\begin{array}{c}\text { Regional Network Project "From Heart to } \\
\text { Heart" }\end{array}$ & 78 & $\begin{array}{l}\text { https://heartkonkurs.0 } \\
\text { 00webhostapp.com/ }\end{array}$ \\
\hline 2019 & $\begin{array}{c}\text { All-Russian project "Methodological } \\
\text { navigator in the digital educational } \\
\text { environment" }\end{array}$ & 229 & https://clck.ru/FYtyc \\
\hline
\end{tabular}

Currently, in Rostov region, subject and interdisciplinary network project activities of teachers together with students are initiated every year. All stages of the project are based on the study of geography, but geography is associated with a number of other academic disciplines [12]. The establishment of organic relationships between geography and these academic subjects not only enriches and deepens the geographical knowledge of schoolchildren, but also has a beneficial effect on the assimilation of related disciplines [13]. Network project activity contributes to the development of the creative qualities of the participants and the organization of joint activities of teachers and students, which is aimed at creating conditions for their self-realization, developing the skills of cognitive, educational research and project activities [14].

\section{Results and discussion}

Analysis of the results of the study of information needs in the context of their practical applicability for teachers of geography made it possible to highlight the following topical issues for inclusion in teacher training programs: standardization of education; questions of methodology and practice of preparation for the state final certification; improving the quality of education; pedagogical features of work based on digital educational platforms and services; inclusion of various models of blended learning in the practice of teaching geography, project activities at school; the formation of universal educational actions; metasubject approach in education; information about new textbooks and teaching aids for schoolchildren and teachers, methodological developments on the subject. The data obtained formed the basis for the development of the concept, structure and organizational and methodological support for the functioning of the network professional community of geography teachers in the Rostov region.

Changes were made to the practice of organizing advanced training for teachers of geography, aimed at creating organizational and pedagogical conditions for the functioning of network interaction of teachers of geography on the basis of project activities. The main directions of changes in the organization of training and methodological support for advanced training were identified: 1) diversification of additional professional advanced training programs for teachers of geography in terms of introducing changes in their content aimed at developing ICT competence, shaping the experience of behavior in social 
networks, acquaintance with modern GIS focused on the development of geographical science and the practice of teaching the subject at school; 2) the development of an information and educational environment for the effective organization of network educational projects: information support and administration of the network community "Geography Teachers of Rostov Region", network communities of municipal methodological associations of geography teachers and updating the network activity of teachers at these sites, development of network activity of geography teachers in a joint work on the development of an electronic educational resource for Rostov region, presentation of professional experience in the Regional Bank of the Center for Educational Development and the Bank of Effective Pedagogical and Management Practice, in printed magazines and publications; 3) development of content and implementation of new forms and methods of teacher training based on the organization of network project activities of teachers, their professional support after completion of training. The indicators diagnosed during the period of professional training of teachers of geography under the conditions of these changes, according to the criterion of personal professional development, are qualitatively different (Table 2).

Table 2. Results of diagnostics of teachers of geography by the criterion of personal professional development.

\begin{tabular}{|c|c|c|c|}
\hline \multirow[t]{2}{*}{ № } & \multirow[t]{2}{*}{ Index } & \multicolumn{2}{|c|}{ Quantitative / qualitative characteristics of the results } \\
\hline & & 2013 & 2019 \\
\hline 1 & $\begin{array}{l}\text { Participation of } \\
\text { geography teachers in } \\
\text { professional } \\
\text { development } \\
\text { programs, other forms } \\
\text { of education and } \\
\text { networking. }\end{array}$ & $\begin{array}{l}\text { Training at improvement } \\
\text { qualification courses (full- } \\
\text { time) } 155 \text { teachers, having } \\
\text { taken part in webinars and } \\
\text { other forms of training in the } \\
\text { network - } 28 \text { teachers. }\end{array}$ & $\begin{array}{l}\text { Training at improvement } \\
\text { qualification courses (full- } \\
\text { time) } 178 \text { teachers, having } \\
\text { taken part in webinars and } \\
\text { other forms of training in the } \\
\text { network - } 338 \text { teachers. }\end{array}$ \\
\hline 2 & $\begin{array}{c}\text { Formation of } \\
\text { professional ICT } \\
\text { competence in the } \\
\text { learning process at } \\
\text { advanced training } \\
\text { courses. }\end{array}$ & $\begin{array}{c}\text { Individual promotion rate: } \\
12.9 \% .\end{array}$ & $\begin{array}{l}\text { Individual promotion rate: } \\
52,4 \% .\end{array}$ \\
\hline 3 & $\begin{array}{c}\text { Analysis of the } \\
\text { publication activity of } \\
\text { teachers. }\end{array}$ & $\begin{array}{l}\text { Having developed workbooks } \\
\text { on geography - } 3 \text { teachers; } \\
\text { articles were published in the } \\
\text { regional methodological } \\
\text { journal - } 1 \text { teacher, other } \\
\text { methodological journals and } \\
\text { conference proceedings, } \\
\text { including online - } 2 \text { teachers. }\end{array}$ & $\begin{array}{c}\text { Having developed } \\
\text { workbooks on geography }-3 \\
\text { teachers; articles were } \\
\text { published in the regional } \\
\text { methodological journal - } 5 \\
\text { teachers; other } \\
\text { methodological journals and } \\
\text { conference proceedings, } \\
\text { including online - 58 } \\
\text { teachers; }\end{array}$ \\
\hline 4 & $\begin{array}{l}\text { The readiness of } \\
\text { teachers for self- } \\
\text { education and self- } \\
\text { development through } \\
\text { determining the } \\
\text { dynamics of their } \\
\text { participation in } \\
\text { network educational } \\
\text { projects. }\end{array}$ & $\begin{array}{l}23 \text { teachers and } 78 \text { students } \\
\text { are registered in the network } \\
\text { educational project "As it is in } \\
\text { the Don", other projects - no } \\
\text { information }\end{array}$ & $\begin{array}{l}229 \text { teachers were registered } \\
\text { in the regional project } \\
\text { "Methodological navigator in } \\
\text { the digital educational } \\
\text { environment", } 80 \text { teachers } \\
\text { developed and carried out } \\
\text { their own projects, } 415 \\
\text { students took part. }\end{array}$ \\
\hline 5 & $\begin{array}{l}\text { The number of } \\
\text { educational, }\end{array}$ & $\begin{array}{c}\text { Published materials } \\
\text { illustrating the experience of }\end{array}$ & $\begin{array}{c}\text { Published materials } \\
\text { illustrating the experience of }\end{array}$ \\
\hline
\end{tabular}




\begin{tabular}{|c|c|c|c|}
\hline $\begin{array}{c}\text { methodological and } \\
\text { electronic educational } \\
\text { resources created by } \\
\text { teachers. }\end{array}$ & $\begin{array}{c}\text { implementing educational } \\
\text { programs in geography - } 2 \\
\text { academic. }\end{array}$ & $\begin{array}{c}\text { implementing educational } \\
\text { programs in geography - 322 } \\
\text { academic units. }\end{array}$ \\
\hline
\end{tabular}

Analysis of the data obtained shows that from 2013 to 2019 the choice of forms of vocational training has expanded: while the number of teachers choosing to attend full-time professional development courses has grown insignificantly, the interest in various forms of online education has grown by more than 10 times. It is necessary to note the significant dynamics of the development of all components of the ICT competence of teachers of geography, which allows us to note the high efficiency of coursework in the field of improving ICT competence using network project activities. An analysis of the publication activity of teachers became a qualitative characteristic of the effectiveness of the proposed model of support for teacher growth: if the number of copyright teaching aids created by teachers has not changed, since their creation requires high professionalism and a level of methodological competence, the number of articles in the regional methodological journal and conference proceedings, including the online ones, increased significantly (from 2 to 58 publications) .In the study period, there was an increase in the number of copyright materials presented in the regional bank of digital educational resources and a bank of effective pedagogical practice, educational methodological and electronic educational resources, created by teachers independently. In 2019, 322 geography teachers posted materials illustrating their own professional experience in implementing educational programs in geography. In the period from 2013 to 2019, the positive dynamics of the participation of teachers of geography of Rostov region in network educational projects remains. In addition, a new trend has been noted regarding the change in the composition of participants in network projects: since 2014, teachers from other regions of the Russian Federation have joined the work on network projects, and since 2015, teachers from neighboring countries have been among the project participants. In 2019, 80 geography teachers developed and conducted their own network projects for schoolchildren, in which more than 400 schoolchildren took part. This trend will obviously remain in 2020, because the transfer of schools to a distance work format in April - May updated this work format.

Thus, network projects of various levels help to solve the following tasks: gaining experience of joint activities in a network of teachers and students, developing the ICT competence of teachers and skills of working with information in schoolchildren; gaining experience in using Web 2.0 services, "cloud" services for analyzing, systematizing, structuring work with educational information at the level of requirements of Russian and international education standards; formation of behavior skills in the world of virtual reality and social networks; promoting the development of students' creative qualities, increasing their cognitive activity and acquiring skills in organizing training using distance learning technologies.

\section{Conclusion}

By creating high-quality products of project activities and posting them on the Internet, teachers and students become the authors of a new educational resource, which can later be used in the educational process. The position of schoolchildren is changing: they become active participants in the educational process, capable not only of learning on their own, but also of teaching their peers [15]. The position of teachers is also changing: they become mentors, coordinators, consultants who are able to create conditions for organizing an educational space in which students are able to receive a qualitatively new education based on the use of Web 2.0 services; their authority among students is growing. Network 
projects are a motivating factor not only for the development of information technologies by schoolchildren, but also for the study of school subjects, the development of their cognitive activity, the actualization of a creative position, and integrated content provides great opportunities for the formation of alternative thinking of students [16]. The product of the implementation of a network integrative project becomes a new electronic educational resource, which is located in the regional information and educational environment and contributes to the achievement of students not only subject, but also meta-subject, as well as personal learning outcomes. Educational resources created on the basis of the organization of networked educational interaction are able to provide: support for all stages of the educational process - obtaining information, practical exercises, monitoring educational achievements; expansion of the self-study sector; changing the role of teacher and student; a sense of responsibility for the result; the student's transition from passive perception of the information presented to active participation in the educational process; implementation of fundamentally new forms and methods of teaching, including selfdirected individual training.

Trends in the development of various forms of teacher training in modern conditions have determined the conceptual foundations for the development of the idea of professional interaction of teachers as a leading one, characterized by continuity; new approaches to assessing the professional competence of teachers; characterization of the system of professional development of teachers as open, variable and personified [17]. The positive experience of organizing training for teachers of geography on the basis of network educational projects has shown the need to transform the system of advanced training based on the targeted provision of educational services and individualization of the educational process, taking into account the principles of independence, reflexivity, cooperation, reliance on life and professional experience, individualization, and development of educational needs.

\section{References}

1. O. Fedotova, Russian Education in the System of Global Interactions: Trends and Theoretical Projection, Procedia - Social and Behavioral Sciences, 214, 414-421 (2015)

2. N. C. Burbules, G. Fan, P. Repp, Five trends of education and technology in a sustainable future Geography and Sustainability, I, 93-97 (2020)

3. O. Fedotova, V. Latun, Y. Merinova, A. Ertel, The evolution of the institutional structure of the agricultural education in Russia E3S Web of Conferences, 175, 15026 (2020)

4. J. A. Barnes, Class and committees in a Norwegian parish island, London. Human relations, 7, 43-44 (1954)

5. H. Garton, W. H. Rheingol, The Virtual Community: Homesteading on the Electronic Frontier, 234 (1993)

6. G. Putnik, C. Alves, Learning material co-creation infrastructure in Social Networkbased Education: An implementation model, Procedia - ScienceDirect, 84, 215-218 (2019)

7. C. Alves, G. Putnik, Experiential Learning of CAD Systems Interoperability in Social Networkbased Education, Procedia - ScienceDirect, 84, 209-214 (2019)

8. K. Sriprasertpapa, W. Langkab, S. Boonlueb, The Development of Thai Teacher Information Communication Technology (ICT) Online Community Model in Thailand, Procedia - Social and Behavioral Sciences, 197, 1727-1731 (2015) 
9. Professional standard "Teacher of primary general, basic general, secondary general education". Available at: http://fgosvo.ru/docs/101/69/2/1 (Last accessed 03/09/2020)

10. UNESCO Associated Schools Network: guide for national coordinators. Available at: https://unesdoc.unesco.org/ark:/48223/pf0000261994 (Last accessed 03/09/2020).

11. G. S. Gorozidis, Y. S. Tzioumakis, C. Krommidas, A. G. Papaioannou, Facebook group PETCoN (Physical Education Teacher Collaborative Network). An innovative approach to PE teacher in-service training: A self-determination theory perspective, Teaching and Teacher Education, Teaching and Teacher Education, 96, 103-184 (2020)

12. A. Adama, Ga. Prosteana, A. Badeaa, O. Prosteanb, Knowledge Transfer in Educational Projects, Procedia - Social and Behavioral Sciences, 191, 1460-1466 (2015)

13. O. Fedotova, V. Latun, I. Okuneva, Visual image of the continent in Russian textbooks on geography (1825-2013), Procedia - Social and Behavioral Sciences, 141, 731 - 737 (2014)

14. A. M. Suduca, M. Bîzoia, G. Gorghiua, L. M. Gorghiub, Using web conferencing for disseminating the educational projects results, Procedia - Social and Behavioral Sciences, 2, 2813 - 2818 (2010)

15. P. Guo, N. Saab, L. S. Post, W. Admiraal, A review of project-based learning in higher education: Student outcomes and measures. International Journal of Educational Research, 102, 101586 (2020)

16. N. Naderpajouh, J. Matinheikki, L. A. Keeys, D. P. Aldrich, I. Linkov, Resilience and projects: An interdisciplinary crossroad, Project Leadership and Society, 1, 100001 (2020)

17. S. N. Kerkhoffa, M. E. Cloudb, Equipping teachers with globally competent practices: A mixed methods study on integrating global competence and teacher education, International Journal of Educational Research, 103, 101629 (2020) 